\title{
A brief overview and checklist of terrestrial Parasitengona mites (Actinotrichida, Trombidiformes) of Latvia
}

\author{
Ineta Salmane ${ }^{1,2 *}$, Joanna Mąkol ${ }^{3}$ \\ ${ }^{1}$ Institute of Biology, University of Latvia, Miera. 3, Salaspils LV-2169, Latvia \\ ${ }^{2}$ Latvian Plant Protection Research Centre, Struktoru 14A, Rìga LV-1039, Latvia \\ ${ }^{3}$ Wroclaw University of Environmental and Life Sciences, Department of Invertebrate Systematics and Ecology, Kożuchowska 5b, \\ 51-631 Wrocław, Poland \\ *Corresponding author, E-mail: chuskauss@yahoo.com
}

\begin{abstract}
Two Erythraeidae (Actinotrichida, Trombidiformes) species, Abrolophus miniatus (Hermann, 1804) and Leptus (Leptus) molochinus (C.L. Koch, 1837), were recorded for the first time in Latvia. The former species was found in the soil and vegetation of a mesophytic meadow, whereas the latter was registered walking alive in a dry insect collection box. A list of terrestrial Parasitengona mites, including members of Erythraeidae, Trombidiidae, Podothrombiidae, Microtrombidiidae and Johnstonianidae, hitherto recorded from Latvia is provided.
\end{abstract}

Key words: Abrolophus, larva, Leptus, mites, postlarva.

\section{Introduction}

Terrestrial Parasitengona mites, including among others the genera Leptus Latreille, 1796 and Abrolophus Berlese, 1891, are regarded as cosmopolitan (Giljarov 1978). Larvae of these mites are parasites of various insects and arachnids or, exceptionally, display a free living life style, while adults and deutonymphs often inhabit plants, humus or open ground, and are predators of small arthropods (Krantz, Walter 2009). Erythraeidae occupy a wide range of habitats from temporarily flooded to dry ones (Wohltmann 2000).

Until now 23 terrestrial Parasitengona species were recorded from Latvia (Grube 1859; Haitlinger 2000; Haitlinger 2010), whereas the updated check-list contains 23 specific level taxa.

\section{Materials}

Material was collected in Rīga county near Dzilnuciems (N $\left.56^{\circ} 55^{\prime} 05^{\prime \prime} \mathrm{E} 23^{\circ} 51^{\prime} 59^{\prime \prime}\right)$ on higher plants and in rhizosphere of the mesophytic meadow, as well as recorded in the dried arthropod collection (personal collection of Dr. biol. D.

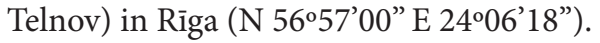

\section{Results and discussion}

Lately three Erythraeidae species were recorded in Latvia: Leptus (Leptus) trimaculatus (Rossi, 1794), Leptus (Leptus) molochinus (C. L. Koch, 1837) and Abrolophus miniatus (Hermann, 1804). The first one was previously recorded by
Grube (1859) from the territory of the former Livland and by Haitlinger $(2000 ; 2010)$ in Abari and Lilaste. The other two Erythraeidae species are new to the fauna of Latvia.

During the field study two larvae of $L$. trimaculatus and one postlarval specimen of $A$. miniatus were recorded from Riga county, near Dzilnuciems on higher plants and in rhizosphere of a mesophytic meadow, 05.07.2006, leg. I. Salmane, det. J. Mąkol. The latter species was recorded by Grube (1859) in Estonia.

Another two larvae of $L$. (L.) molochinus were found in a dried arthropod collection in Rìga, 20.10.2012, leg. D. Telnov, det. J. Mąkol. These specimens were walking alive inside the dry insect collection box. Obviously, they were attached to their host insects during the collecting and were brought to the collection box. Previously, this species was recorded in Estonia by Haitlinger (2010).

The data on life cycle of $L$. trimaculatus, along with the first description of larva, was provided by Wendt et al. (1992). The life history of L. molochinus was studied by Łaydanowicz and Mąkol (2010). Abrolophus miniatus remains known exclusively from active postlarval forms and has been considered a common and ubiquitous species in Poland (Gabryś , Mąkol 2008).

List of terrestrial Parasitengona species recorded in Latvia is presented in Table 1.

Haitlinger (2010) reported Charletonia cardinalis (C.L. Koch, 1837) as new to the fauna of Latvia, however an earlier record was provided by Grube (1859). The same author provided new locality records for Trombidium holosericeum (L.): Seriijai and Zarasai and assigned 
Table 1. List of terrestrial Parasitengona species recorded in Latvia

\begin{tabular}{|c|c|c|}
\hline Family & No. & Species \\
\hline \multirow[t]{16}{*}{ Erythraeidae } & 1 & Abrolophus miniatus (Hermann, 1804), new to Latvia. \\
\hline & 2 & Abrolophus norvegicus (Thor, 1900): Haitlinger 2010. \\
\hline & 3 & Abrolophus quisquiliarus (Hermann, 1804): Grube 1859. \\
\hline & 4 & Abrolophus wratislaviensis (Haitlinger, 1986): Haitlinger 2010. \\
\hline & 5 & Balaustium crocatus (C.L. Koch, 1837): Grube 1859 [as Erythraeus (E.) crocatus (C.L. Koch, 1837)]. \\
\hline & 6 & Balaustium kacperi Haitlinger, 1996: Haitlinger 2010. \\
\hline & 7 & Charletonia cardinalis (C.L. Koch, 1837): Grube 1859. \\
\hline & 8 & Erythraeus (E.) opilionoides (C.L. Koch, 1837): Grube 1859. \\
\hline & 9 & Erythraeus (E.) phalangoides (De Geer, 1778): Grube 1859. \\
\hline & 10 & Erythraeus (E.) principalis (C.L. Koch, 1837): Grube 1859. \\
\hline & 11 & $\begin{array}{l}\text { Erythraeus regalis (C.L. Koch, 1837): Haitlinger } 2010 \text { [as Erythraeus (E.) kuyperi (Oudemans, 1910)]; } \\
\text { for synonymy see: Stålstedt et al. 2016. }\end{array}$ \\
\hline & 12 & Erythraeus (E.) rupestris (Linnaeus, 1758): Grube 1859. \\
\hline & 13 & Leptus (L.) mariae Haitlinger, 1987: Haitlinger 2010. \\
\hline & 14 & Leptus (L.) molochinus (C. L. Koch, 1837): new to Latvia. \\
\hline & 15 & Leptus (L.) rubricatus (C.L. Koch, 1837): Grube 1859. \\
\hline & 16 & Leptus (L.) trimaculatus (Rossi, 1794): Grube 1859. \\
\hline \multirow[t]{3}{*}{ Trombidiidae } & 17 & $\begin{array}{l}\text { [?] Allothrombium fuliginosum (Hermann, 1804): Grube } 1859 \text { (as Trombidium erythrellum C.L. Koch, } \\
\text { 1837); for synonymy see: Mąkol 2000; Wohltmann et al. } 2007 .\end{array}$ \\
\hline & 18 & Trombidium holosericeum (Linnaeus, 1758): Haitlinger 2000. \\
\hline & 19 & Trombidium rimosum C.L. Koch, 1837: Grube 1859. \\
\hline Podothrombiidae & 20 & $\begin{array}{l}\text { Podothrombium filipes (C.L. Koch, 1837): Haitlinger } 2010 \text { (as Podothrombium roari Haitlinger, 2000); } \\
\text { for synonymy see: Mąkol } 2005 .\end{array}$ \\
\hline \multirow[t]{2}{*}{ Microtrombidiidae } & 21 & Dimorphothrombium plancum (C.L. Koch, 1837): Grube 1859. \\
\hline & 22 & Platytrombidium fasciatum (C.L. Koch, 1836): Grube 1859. \\
\hline Johnstonianidae & 23 & Johnstoniana eximia (Berlese, 1910): Haitlinger 2010. \\
\hline
\end{tabular}

both sites to Latvia, while they are located in Lithuania (Haitlinger 2010). Gabryś (2016) considered the Erythraeus (Erythraeus) crocatus (C.L. Koch, 1837) a synonym of Balaustium murorum (Hermann 1804), however without causal reasoning addressed to species level taxa.

\section{Acknowledgements}

Authors are grateful to Dr. biol. D. Telnov (Entomological Society of Latvia) for loaning specimens for identification and to the Ministry of Defence of Latvia and its funded project No. C-096, in the frames of which a part of the material was collected.

\section{References}

Gabryś G. 2016. Commentary on synonyms within Palaearctic Erythraeidae (Acari: Actinotrichida: Parasitengona). Annals of the Upper Silesian Museum (Bytom). Natural History 22: $1-8$.

Gabryś G., Mąkol J. 2008. Erythraeoidea. Pp. 142-145, 209-210. In: Bogdanowicz W., Chudzicka E., Pilipiuk I., E. Skibińska (eds) Fauna of Poland: Characteristics and Checklist of Species. Muzeum i Instytut Zoologii PAN, Warszawa, 3, 603 pp.

Giljarov M.S. 1978. Identification Keys for Soil Inhabiting Mites. Trombidiformes. Nauka, Moscow. /in Russian/

Grube A.E. 1859. Verzeichniss der Arachnoiden Liv-, Kur- und
Ehstlands. Dorpat, 72 pp.

Haitlinger R. 2000. Mites (Acari: Prostigmata: Erythraeidae, Trombidiidae) new to the fauna of Norway, Finland, Russia, Latvia and Lithuania, with a description of Podothrombium roari n. sp. Entomol. Fenn. 11: 187-193.

Haitlinger R. 2010. New records of mites (Acari: Prostigmata: Calyptostomatidae, Erythraeidae, Johnstonianiidae, Microtrombidiidae, Podothrombiidae, Trombidiidae) from Estonia, Latvia and Lithuania. Zeszyty Naukowe Uniwersytetu Przyrodniczego we Wrocławiu, Seria Biologia i Hodowla Zwierząt LXI 579: 49-55.

Koch C.L. 1837. Deutschlands Crustaceen, Myriapoden und Arachniden. Ein Beitrag zur Deutschen Fauna von C.L. Koch. Regensburg, fasc. 10-16.

Krantz G.W., Walter D.E. 2009. A Manual of Acarology. $3^{\text {rd }}$ Ed. Texas Tech University Press.

Łaydanowicz J., Mąkol J. 2010. Correlation of heteromorphic life instars in terrestrial Parasitengona mites and its impact on taxonomy - the case of Leptus molochinus (C. L. Koch, 1837) and L. ignotus (Oudemans, 1903) (Acari: Actinotrichida: Prostigmata: Erythraeidae). J. Nat. Hist. 44: 669-697.

Mąkol J. 2005. Trombidiidae (Acari: Actinotrichida: Trombidioidea) of Poland. Fauna Poloniae. Museum and Institute of Zoology, Polish Academy of Sciences, Natura Optima Dux Foundation, Warsaw, Vol. 1 [NS]: 1-259.

Oudemans A.C. 1937. Kritsch historisch Overzicht der acarologie. Vol. 3, 1805-1850. E.J. Brill, Leiden. p. i-ci + 1-3379. 
Stålstedt J., Wohltmann A., Bergsten J., Mąkol J. 2016. Towards resolving the double classification in Erythraeus (Actinotrichida: Erythraeidae): matching larvae with adults using 28s sequence data and experimental rearing. Org. Div. Evol. 16: 761-790.

Wendt F.E., Olomski R., Leimann J., Wohltmann A. 1992. Parasitism, life cycle and phenology of Leptus trimaculatus (Hermann, 1804) (Acari: Parasitengonae: Erythraeidae) including a description of the larva. Acarologia 33: 55-68.

Wohltmann A.2000. The evolution of life histories in Parasitengona (Acari: Prostigmata). Acarologia 41:145-204.

Wohltmann A., Gabryś G., Mąkol J. 2007. Acari: Terrestrial Parasitengona inhabiting transient biotopes. In: Gerecke R. (ed) Süßwasserfauna von Mitteleuropa 7/2-1, Chelicerata, Araneae, Acari I: 158-240. Spektrum Elsevier, München. 